\title{
Laraine O'Connell
}

\section{J.M. Coetzee's Life and Times of Michael $K$ and Foe as Postmodernist Allegories}

\begin{abstract}
Opsomming
J.M. Coetzee is een van die kontemporêre skrywers vir wie postmodernistiese allegorie 'n bruikbare metafoor geword het. Sy verhale karteer die geaardheid, implikasies en gevolge van die misbruik van mag, en die mite van kolonialisme word ontleed en onthul.

Life and Times of Michael $K$ kan op die universele sowel as op die spesifiek Suid-Afrikaanse vlak geïnterpreteer word. Michael $\mathrm{K}$ word die simbool van die mens se persoonlike vryheid, persoonlike identiteit en waardigheid. Sy stryd om vryheid is ironies in die lig van die feit dat die oorlog waaraan hy probeer ontkom, geveg word juis om minderheidsgroepe inspraak in hulle toekoms te verseker.

Foe ondersoek die verhouding van vertelling en gebeure, waarheid en fiksie. Friday se stilte word 'n manifestasie van die eksistensiële niet. Soos dit in hierdie roman ontplooi, is dit die taak van die skrywer om die gemeenskap aan homself te openbaar, sodat die spraaklose weer resonasie gegee word.
\end{abstract}

Allegory has held an important place in South African literature from a very early stage in its history, in Afrikaans literature developing from the naively didactic novellas of $J$. Lion Cachet, to the sophisticated modern allegories of authors like Etienne Leroux, Berta Smit and Anna M. Louw. In English South African literature Cherry Wilhelm traces allegory as far back as Olive Schreiner's fictions. In her Auetsa paper (1979) Wilhelm says that Schreiner's fictions "can best be understood as modern allegories, as extended narrative metaphors for the soul's timeless quest for the truth, but modified by the particular dilemma of the nineteenth-century soul, which needed to move out of the confining guilts of a punitive theology to the freer air of a new philosophical or artistic synthesis" (65). 
Certain trends have manifested themselves within the system to which the South African novel belongs. There is general dissatisfaction with the present social order. Significantly, religion as a theme seems to have disappeared from the literary scene. Authors have begun to experiment with point of view, and fantasy and surrealism have become important devices. Irony and satire have become far more pervasive than in the past.

Gareth Cornwell (1983:24) makes the tentative suggestion that the front rank of South African writers - Coetzee, Gordimer, Gray, Brink, Peter Wilhelm - is turning away from the present to an imagined future, a re-animated past or a timeless zone outside history in its search for a workable metaphor. Postmodernist allegory appears to provide a workable metaphor for these writers.

Coetzee meets the modern reader's demand for realism. His realism is fantastic, yet nevertheless frighteningly real. In charting the nature, implications and consequences of the imposition of power, the Western myth of colonialism in all its forms is dissected and revealed for what it is. All Coetzee's fictions reiterate the basic political allegory defined by Hegel (1949) in an essay entitled 'Independence and Dependence of Self-Consciousness, Lordship and Bondage' in The Phenomenology of the Mind. In this essay Hegel proposes that the master and the servant are mutually dependent, but that the servant, not the master, embodies the potential for renewal: the master inevitably grows less productive as he grows more dependent, and the servant's growth in power is directly proportionate to his awareness of his master's growing dependence.

Life and Times of Michael $K$ is an allegory that can be interpreted on at least two levels, the universal, and the specifically South African. The streets, the Sea Point beach front and the remote Prince Albert district are all recognisably South African, and Coetzee manages to evoke through his spare narrative the harshness of the Cape winter and the aridity but singular beauty of the Karoo with a sureness of touch only possible for one intimately familiar with the region.

But the landscape travelled by Michael $K$ is a cold, unfriendly one. It is a landscape of abandoned beach-front flats, deserted farms, convoys and camps. The restriction of permits, curfews and camps of a war-stricken country could be anywhere in the world, but the South African reader cannot escape the implications of the story for South African society. The characters and the action are stripped down to the barest essentials. The looters, deserters and bureaucrats he comes across are all in some way or the other attempting to effect compromises in order to survive.

Michael K's Kafkaesque name prepares the reader for the universality of the issues to be examined, but Michael also means "like God", and he becomes the symbol for man's personal freedom, personal identity and dignity (Müller, 
1985:41), which he manages to retain inviolate in spite of all the hardships he suffers. He is a skeletal figure, a universal nobody whom we can never know intimately, though we may feel as he does (Smith, 1983:28).

Despite his name, Michael $\mathrm{K}$ is given a very personal identity in the first lines of the novel. He is born with a harelip, a lip curling like a snail's foot, and a gaping left nostril. He is neither welcome nor loved, and his first years, spent with his mother, are devoted to learning to be quiet. By an accident of birth he is "but one of a multitude in the second-class" (Coetzee, 1983:187). He becomes a condemnation, not only of the racist nature of the South African political system, but of oppression of the individual, regardless of colour or race.

While this novel might appear to be occupied with something different, it examines an aspect of colonialism as well. Its protagonist is intent on avoiding colonisation in any form, and he embodies the major theme of the novel. It is this drive of the individual to assert his independence, through flight or through non-cooperation, that raises the novel to a manifestation of a more prevailing "universal truth".

His childhood is spent at Huis Norenius, a home for variously handicapped children, where he learns the skills that will suit him for his second-class life. Having been discharged from Huis Norenius at the age of fifteen, he is soon revealed as a creature of solitude, shadow and damp, like the snail that is suggested by his harelip, preferring to work in the parks with the tall pines and dim agapanthus walks (Coetzee, 1983:5).

The conditions in the city are sketched with just sufficient detail to suggest a landscape of war. The hospital in which his mother is being treated for dropsy is inundated with war casualties. The irregularity of the bus service serves to convey the never overtly stated disruption caused by civil war which is a vaguely delineated but persistent backdrop to events.

The journey they decide to undertake to escape the city is one of the oldest allegorical devices, allowing characters to be introduced to changing circumstances, and revealing development of character.

The idea of returning to the Karoo of Anna's birth by train has to be given up although Michael has bought the tickets, because of the impossibility of penetrating the Kafkaesque bureaucracy, complicated by the war conditions. Michael builds a barrow in which to push his mother, and begins the journey, which becomes an infernal ordeal. They are turned back, harassed by would-be robbers, laughed at by passers-by and only once offered a lift, while Anna becomes progressively weaker. At Stellenbosch he has to give up and take her to hospital.

After his mother's death and cremation, he wanders around with his barrow and her ashes, reluctant to move on. Robbed first of his barrow and then of his money, he discards everything except his mother's coat and her ashes. He is systematically being stripped of his material possessions, as his body is 
being stripped of flesh by the privations of his journey. "Living off the land" (63) but mostly going hungry, he feels a strange affinity with this desolate and barren country.

He has a basic sense of the permanence of nature. When his mother remarks of a magazine picture that "People don't eat like that any more" (21), he disagrees. "'The pigs don't know there is a war on,' he said. 'The pineapples don't know there is a war on. Food keeps growing"' (21). On the deserted Visagie farm he acknowledges to himself that he is a gardener, and experiences intense joy in the activity of tending his little garden and irrigating it from the dam. He appears to be existing in "a pocket outside time" (82).

Reduced to eating insects while tending his pumpkin plants, and feeling no appetite, he tells himself that when food comes out of the earth he will recover his appetite, for such food will have savour (139).

When he arrives on the farm for the first time, he thinks of one of the parks where he worked, and presumes that the grass has not stopped growing because there is a war. But he has lost his affinity for the dark and damp. He has emerged into the sunlight of the Karoo and found greater affinity with the hardness, the dry yellow and red of his mother's country.

When he returns to the farm, however, he is gradually compelled to become a creature of the night once again, moving on the darkest of nights with the confidence of a blind person, taking care of his plants, chasing away the wild goats that trample them. The thought that prevents him from joining the men from the mountains is that enough men had gone off to the war saying that the time for gardening was over. He has the mystical awareness that contact with the earth must be maintained, "because once that cord was broken, the earth would grow hard and forget her children" (150).

Eating the first fruit of his labour is an intensely sensual experience, bringing tears to his eyes, his heart brimming over with gratitude. But the damage to his body has progressed too far, symbolising the irreparable damage done to the individual by being deprived of his identity, and when the soldiers arrive again, he has no defence, beyond taking with him a packet of seed.

The individual's right to freedom, the freedom insisted upon by even this most minimal of beings, is emphasised throughout the novel. At Worcester Michael is picked up for not having a permit, and is assigned to a gang to clear the railway line, until he all but collapses, yet finds the energy to assert his rights, "Why have I got to work here?" (58). The next day, quietly and unnoticed, he mingles with another gang of workers and boards the northbound train with them.

The first real kindness he experiences is that of the family that gives him food and shelter for a night in Laingsburg. The man expresses his code of decency: "People must help each other, that's what I believe" (65). Later K is the only one who reacts when their former guard is stabbed in the leg - perhaps he is after all one of those who believe in helping others. 
The arrival on the farm of the owner's grandson ends his illusion of freedom, and when there is another assault on his right to his own identity, he moves on. He refuses to be made into a servant by the young deserter, and takes to the road once more.

Having to quit the mountain camp when the hunger becomes too acute, he is taken to a resettlement camp, a nightmare return to his childhood, to Huis Norenius.

Robert's comments on the camp system are a bitter indictment of conditions in South Africa, caused among other things by apartheid and the Group Areas Act: "What they would really like ... is for the camp to be miles away in the middle of the Koup out of sight. Then we could come on tiptoe in the middle of the night like fairies to do their work, dig their gardens, wash their pots, and be gone in the morning leaving everything nice and clean" (112). He also mentions the system as a source of cheap labour, "and at the end of the day the truck fetches them and they are gone and he doesn't have to worry about them or their families, they can starve, they can be cold, he knows nothing, it's none of his business" (112).

Michael is completely egocentric in his attitude, unaware of anything that does not directly affect his own freedom. He has no understanding of and no interest in this war which persists in dogging him. Robert's is the voice slowly penetrating his sluggish mind, making him conscious, so that looking at the girl who has lost her baby, it seems that scene after scene is playing itself out before him and that the scenes all coalesce. He has a presentiment of a single meaning upon which they are converging, but he does not yet know what the meaning might be (122). Slowly Michael's thoughts begin to waken as the seed that Robert has planted begins to grow and he recognises the intrinsic truth of many of his comments. The image of planting and growth is continued and he 'watches' the thought take shape in his mind and grow, like a plant.

It is ironic that the wrath visited upon the camp by the police officer is the result of an explosion in town after which the resultant fire spread to the cultural history museum and burnt it to the ground - ironic because it suggests that that which is preserved in museums is perhaps all that is left of South African culture.

When Michael climbs over the fence of the camp to claim his freedom once again, he describes the ground outside as being very much like the ground inside, suggesting that the whole country has become a prison, and that freedom is not necessarily physical freedom. Back on the farm he is wary of committing the same mistakes as his predecessors. He resists the temptation to carry the Visagies' rubbish to his home, although he has use for most of the things. "The worst mistake, he told himself, would be to try to found a new house, a rival line, on his small beginnings out at the dam. Even his tools should be of wood and leather and gut, materials the insects would eat when one day he no longer needed them" (143). 
As in his other novels, Coetzee explores the Hegelian theme of mastery and slavery, revealed in the oppression of one section of the inhabitants by the other. Another version is Michael's speculation on the role of parasite and host. "It was no longer obvious which was parasite, camp or town ... What if the hosts were far outnumbered by the parasites . . . could the parasites then still be called parasites? .. . Perhaps in truth whether the camp was declared a parasite on the town or the town a parasite on the camp depended on no more than on who made his voice heard loudest" (159-160). But Michael's voice is too soft to be heard. He is perhaps what Magda (Coetzee: 1977) desired to be, not master or slave, but the bridge in between.

The second part of the novel is a presentation of a wide range of South African attitudes. The women overheard in the canteen are expressing their bitterness at having been evacuated, and their fears are those that are expressed about the barbarians in Waiting for the Barbarians: "In her dreams of her abandoned home a strange man sprawls on the sheets with his boots on, or opens the deep-freeze and spits into the ice-cream" (Coetzee, 1983:183). The doctor and his friend represent "the enlightened liberal whose humanitarian efforts fall short of true Christianity because he remains trapped within the system" (Müller, 1985:41). At the opposite extreme is the callous Sergeant Albrechts who justifies his cruel inhumanity by saying that he is only acting in accordance with the rules.

Michael is now known as Michaels, despite his insistence that his name is Michael, symbolising even the doctor's refusal to recognise his individuality. The world has no respect for Michael K's freedom and identity. The doctor wants to flesh him out to become Michaels; they attempt to make him adopt the identity of a criminal siding with the insurgents, but he refuses to be categorised.

Michael appears to the doctor to have transcended the condition of war in the country. He recognises the irony of Michael's being detained as an insurgent when he barely knows that there is a war on. When Michael declares, "I am what I am", he is taking his stand for freedom against these well-meaning bureaucrats who are still attempting to categorise him. He is as unaffected by what has happened to him as a stone, "a pebble that, having lain around quietly minding its own business since the dawn of time, is now suddenly picked up and tossed randomly from hand to hand" (185). His reply to a renewed bout of interrogation is simply, "I am not in the war" (189). But the warning is there - there is no home left for the universal souls (207), and compromise is the only way to survive.

Michael resists their attempts to fatten him up, perhaps because he knows that the purpose is not to give him his freedom, but to make him fit for camp life. Even their exaggerated concern he shakes off impatiently, because too close attention also implies curtailment of his freedom. He insists that he is not going to die, but that he simply cannot eat the camp food.

The doctor visualises Michael as the rudimentary, elemental, universal man, 
who has managed "[to pass] through the bowels of the state undigested; he has emerged from its camps as intact as he emerged from its schools and orphanages" (221). The intense irony of their inability to accommodate Michael and his claim to identity is revealed when the doctor asks why they are fighting the war, and Noël replies that it is "so that minorities will have a say in their destinies" (215). To claim that right Michael has to escape, and by his escape he succeeds at least in revealing to the doctor that the only acceptable life is a life of freedom.

In this second part Michael's likeness to Christ, as suggested by his name, is also emphasised. Soon after his arrival at the hospital, the doctor remarks that "I am not sure he is wholly of our world" (178). When Michael insists that "I am what I am" (179), the analogy with the identity claimed by God, "I am", is evident. He is the obscurist of the obscure, "so obscure as to be a prodigy" (195). The dark pools of his eyes seem to look at the doctor from beyond the grave.

The doctor's agonizing after Michael has disappeared comes closest to revealing the Christ-image that he has become, at least to the doctor. He desires intensely to accompany Michael, to be able to move with him into a space outside history, between the camps, belonging to no camp. He imagines saying to Michael, "Your stay in the camp was merely an allegory - speaking at the highest level - of how scandalously, how outrageously a meaning can take up residence in a system without becoming a term in it. Did you not notice how, whenever I tried to pin you down, you slipped away?" (228).

In the third section Michael's freedom is compromised once again by the charity of the vagrants he runs into. They too refuse to recognise his identity, and he is called $\mathrm{Mr}$ Treefeller, after the name emblazoned on his stolen overalls. They give him food and drink, wrap him in a plastic sheet for his night with them in the open, under the pine trees on the mountainside, and attempt to rob him in the night. They succeed only in scattering his pumpkin seeds, but he manages to recover some of them to take with him again. They catch up with him on the beach, but he remains strangely innocent and inviolate despite the twin temptations of alcohol and sex that they offer him.

Back in his mother's room, the circular journey, the odyssey, has been completed. Michael has travelled from nowhere to nowhere. He has not experienced an advance in learning, or a growth of selfawareness, but he has survived, above all, with his spirit intact. He recognises that he is essentially a gardener. Many seeds from one is what he calls "the bounty of the earth" (162), and he feels that the one mistake he made was not to have more seeds, many kinds, hidden about his person, to escape the eyes and hands of robbers.

Lying wrapped in another man's blanket in his mother's old room he fantasizes about undertaking a return to the farm with this (imagined) old man to whom the blanket belongs, to plant his seeds. It doesn't matter that the reader recognizes that this will not happen, that Michael $\mathrm{K}$ is dying. What 
does matter is that he has survived the Kafkaesque machinery of oppression and asserted his right to freedom, no matter how minimal that freedom is.

Michael $\mathrm{K}$ is an individual, but also the whole black people of South Africa, and, at a further narrative level, the deprived, oppressed, second-class people of the world. His personal destiny figures the destiny of the collective. The final application of the allegory is that the true salvation of society lies in the recognition of the basic equality, humanity and individual freedom that Michael K symbolises (Müller: 43). The author seems to be asking, "Shall the meek inherit the earth?" (Blake, 1984:56). But like any other profound allegory, Life and Times of Michael $K$ leaves the question unanswered, and Michael $\mathrm{K}$ himself remains a haunting enigma.

Foe, Coetzee's latest novel, is an allegory which considers themes that have been viewed from other perspectives in his earlier novels, and which extends his exploration of language and meaning, colonialism, sexuality, dominance and subservience, and the predicament of the autobiographer/writer of stories. Foe appears to be an investigation of the slippery nature of truth and its relation to story-telling, the nature of fiction and historicity, and writing itself.

In Lord of the Flies Golding reoccupies R.M. Ballantyne's coral island, and shows Ballantyne's portrayal of the four "English boys" to be false, by repopulating the island with boys who are not idealised, but carry within themselves the essential evil that is inherent in man. In Foe Coetzee reoccupies another island, this time Defoe's, with a morose master who has taught his slave only sufficient English for him to understand the basic instructions necessary to carry out the simple activities on the island, and Friday himself, a far more realistic primitive than Defoe's Walt Disney-type barbarian.

Foe consists of four parts, each employing a change in time, place, characters and narrational style. The first part tells the pretext Robinson Crusoe, from a fresh perspective. Robinson Crusoe is generally recognised as the first novel in English literature, which makes it a particularly suitable choice for Coetzee's purpose. His history differs significantly from the original, allowing him to pursue exploration of such problems as translation and interpretation. To the two men on the island, he adds a woman, Susan Barton, who takes over the narrative from Defoe's Crusoe, and a subdued but constant note of sexuality is introduced which was absent from the original.

The novel begins with a story being told. Susan Barton is relating to Foe the story of her arrival and sojourn on the island. She makes a point of indicating the difference between reality and imagination when she focuses attention on the difference between the popular conception of the desert isle with its soft sands and shady trees, "where brooks run to quench the castaway's thirst and ripe fruit falls into his hand, where no more is asked of him than to drowse the days away till a ship calls to fetch him home" (Coetzee, 1986:7), and the rocky island where she lands, dotted with drab bushes, with evil-smelling off-shore 
beds of seaweed and swarms of fleas, and also lizards, apes and birds (7). There is also an ironic contrast between the romanticized castaway's "drowsing the days away" and her utter boredom and depression.

Her first action after taking care of her most elementary needs for survival, drinking water and ending the pain in her foot by removing a thorn, is to proceed to tell Cruso and Friday the story of her life. In this narration, a story within a story, she provides her story with a past in relation to the immediate present: she tells of her futile search for her daughter in Bahia, her journey to Portugal which was never completed, the mutiny, and being cast away near the island $(10-11)$. Having told her story, she is drawn into the order under which Cruso lives as master, and Friday as slave, Susan being relegated to the undefined position of a kind of second slave in the island hierarchy.

Cruso is unwilling to tell his story, and when he does relate fragments, he tells a number of versions, which suggest their fictionality. Susan insists that he should have written his history down, with the individual details that would make the story his particular story, and not merely some universal castaway's narrative that could have been anyone's. Friday has no tongue, so that his story cannot be told.

The question of Friday's having no tongue leads to an extended discussion between Cruso and Susan. He gives a multiplicity of reasons why Friday's captors might have done such a thing. Cruso tells Friday to sing, and calls the low, tuneless humming sound "the voice of man", suggesting the inarticulacy of man in the metaphor of the universe. Friday's experience, his whole voice whereby his history might be expressed has been erased within the mental framework of colonialism, reduced at least to the inarticulate humming that reveals his presence, but conveys no meaning, a sound of infinite sadness.

This discussion leads to another, the question of the necessity of slaves, to the existence of whom Providence has shut its eyes. "If Providence were to watch over all of us ... who would be left to pick the cotton and cut the sugar-cane?" (23). This cynical remark reveals Cruso's expansionist, colonising-mercantilist background, and the economic considerations behind the "civilizing" myth of colonialism. Skinner suggests that the analogy of South Africa's imperialistic nationalism presents a relatively accessible complex of allegorical possibilities. "[Coetzee's] choice of re-visioning Defoe and his works of postmodern palimpsest is a highly effective use of historical resonances, allowing him to continue his exploration of colonialism and power in a temporally extended context, not merely in their current and local form" (1986a:86).

This conversation awakens in Susan, who has previously paid as little attention to Friday as to the houseslaves in Brazil, an intense awareness of the inarticulate slave, which is not a feeling of affinity for someone in a plight similar to her own, as slave to Cruso, but a feeling of revulsion.

Having made for herself a cap with earshields, and making use of plugs to shut out the sound of the wind, Susan becomes as deaf as Friday is mute - "What 
difference did it make on an island where no one spoke?" (35). This absence of communication has a bestializing effect on her, and for a while her life degenerates into the sub-human. Cruso impresses a morose silence on her life, yet has patience with her moods. What effect the silence has on Friday cannot be judged.

Cruso has no stories to tell of the life he led as a trader and planter before the shipwreck. He is not interested in Susan's stories and seems not to hear them. He appears to want to pretend that their stories begin and end on the island. $\mathrm{He}$ is not interested in anything but survival: "We sleep, we eat, we live. We have no need of tools" (32), indicative perhaps of the tunnel-vision suffered by many latter-day colonialists. All Cruso's time and energy appear to be engaged in constructing terraces. There are twelve levels, twenty paces deep, banked with stone walls a yard thick, at the highest the height of a man. A hundred thousand or more stones have gone into the construction. Cruso has prepared the seedbeds, but "the planting is not for us. We have nothing to plant - that is our misfortune ... The planting is reserved for those who come after us and have the foresight to bring seed. I only clear the ground for them" (33). This sentiment suggests Coetzee's feeling for history, that no era is ever self-contained, but merely serves as a seedbed for the seed of the next era. There is irony in the suggestion that in Defoe's era the seedbed for colonialism is prepared with the silent collaboration of the slave, in which the seed of neo-colonialism and eventually of apartheid is sown, and from which its dark fruit is harvested.

After more than a year has elapsed, a merchantman, the John Hobart 'rescues' the three castaways. In fact, only Susan is rescued. The men are removed against their will, Cruso because he is too ill to resist strongly enough, and Friday because he has no choice. Cruso suffers from a recurring fever, but he dies of woe, for the kingdom he has been deprived of (43), the kingdom of complete, unchallenged power, which is the colonialist's dream.

Susan tells Captain Smith her story, and he urges her to set it down but she indicates the difference between oral and written literature: "A liveliness is lost in the writing down which must be supplied by art" (40). When the captain suggests that a writer may be hired who will add a dash of colour, she insists that "I will not have any lies told" (40), which immediately introduces fascinating glimpses of levels of narrative, the essential difference between experience and the narration of that experience. "If I cannot come forward, as author, and swear to the truth of my tale, what will be the worth of it? I might as well have dreamed it in a snug bed in Chichester" (40). This last is an ironic reference to the fact that Defoe, the author of the pre-text, had never travelled abroad but had based his novel on the published account of the experiences of one Alexander Selkirk.

In the fascinating meta-text, Coetzee explores the relationship between source and author, truth and fiction. He describes the various stages between the actual events upon which a novel is based and the reader's perception of 
the words in print. The process becomes even more interesting when one considers Foe in relation to Defoe's Robinson Crusoe, even going so far as to imagine a relationship between the idea on which Robinson Cruso is based, and the modern reader of Foe Hough, 1987:12).

The second part of the novel takes the form of letters written to Foe, containing references to the self-consciousness of the author as creator, and his power to make choices: "I think of you as a steersman steering the great hulk of the house through the nights and days, peering ahead for signs of the storm" (50). Her letters communicate the problems that she and Friday encounter in their fight for survival, but more important are her attempts to come to terms with the relationship between narrative and fact, between history, and the time in which the event actually took place. She describes the written account of the year on the island: "It is a sorry, limping affair (the history, not the time itself)" (47).

She imagines the interior of Foe's attic, even to the ripple in the glass of the window. This ripple becomes an image of the ease with which perspective may change, and with it the entire aspect of the event to be narrated. His view of the landscape may be changed by something as insignificant as a movement of the head. In the light of this it is clear that she cannot tell Cruso's story, for only he can tell it from his particular perspective. She feels that she should have concentrated to a greater extent on her own story, telling more about herself, less about him, and she then proceeds to name a bewildering number of details and perspectives that she might have employed, revealing the infinite array of choices with which the author is continually confronted, together with the wholly contingent nature of "reality".

The plethora of choices into which her desire to write her island history has precipitated her, appears to dissolve her very life into ephemerality, robbing her of her own substantiality, "For though my story gives the truth, it does not give the substance of the truth" (51).

She comes to certain insights, recognising as the essence of creativity the ability to remove the self to the imagined world. She also understands that in writing there is more at stake than the history, for it must not only tell the truth, but also please its readers. There is some suggestion of the author's inability to determine the precise identity of his reader, when she tosses the pages of one of her letters to Foe out of the window, to be read by whoever will.

Federman (1973:43) has the following to say about writing: "While pretending to be telling the story of his life, or the story of any life, the fiction writer can at the same time tell the story of the story he is telling, the story of the language he is employing, the story of the methods he is using, the story of the pencil or the typewriter he is using to write his story, the story of the fiction he is inventing, and even the story of the anguish (or joy) he is feeling while telling his story". This is in effect what Coetzee is doing in this novel, and what Susan does when she sits down at Foe's bureau: "I sat at your bureau this 
morning ... and took out a clean sheet of paper and dipped pen in ink - your pen, your ink, I know, but somehow the pen becomes mine while I write with it, as though growing out of my hand" (66-67).

The question of domination and subservience is considered in this novel, and not only in relation to Cruso and his man Friday. When Susan pleads to be taken into Foe's house, offering to be his servant, Coetzee suggests that slavery, degrading as it is, is often entered into voluntarily, purely as a means of survival.

Susan is bound to Friday by her compassion, and her feeling of responsibility. His silence is a constant source of confusion to her, being unable to interpret or understand it. She believes that to live in silence is to drift in an ocean like a whale, or to sit like a spider in the heart of his web, under the misapprehension that his web is the whole world (59).

Attempting to break through his silence to his understanding, she tells Friday about the book Foe is writing about the year the three of them spent together on the island, and about as much else as Cruso told her about their life prior to their arrival. Her desire is to build a bridge of words over which he may cross to the time before he lost his tongue (60). She also admits, though, that although she tells herself that she talks to Friday to educate him out of darkness and silence, she often uses words as the shortest way to subject him to her will, and she understands why Cruso preferred not to disturb his muteness, she can understand why man will choose to be a slaveowner (60-61). Nevertheless, she admits her commitment: "A woman may bear a child she does not want, and rear it without loving it, yet be ready to defend it with her life ... I do not love him [Friday], but he is mine" (111).

Considering the story she has to tell, Susan recognises the paucity of interesting detail, and considers those that might be added, which are strongly reminiscent of details in Defoe's novel. An innovation is the arrival of a golden-haired stranger with a sack of corn to plant on the terraces (67), suggesting perhaps the European colonizer, in the guise of a golden-haired saviour.

Going over the mysteries of her story, she asks herself the questions that a reader might ask, and considers the various ways in which these questions might be answered. The questions she raises concern the futile nature of Cruso's work on the island, the reason for Friday's submission to slavery, her own failure to excite desire in Cruso, and what Friday was about when he paddled out to strew petals on the water. The multiplicity of possible answers illustrates once again the many choices open to the author, while the limited number of events suggest that the historians of earlier castaways have had to make up lies in despair (88). She uses the image of a painter grouping together figures in positions and combinations which may be true on one day and not on another, merely to render his composition lively. She feels that the task of the story-teller is more complex: "The storyteller, by contrast . . . must divine which episodes of his history hold promise of fullness, and trace from 
them their hidden meanings, braiding these together as one braids rope" $(88-89)$.

The advent of the daughter represents another story: "She is more your daughter [figment] than she ever was mine" (75), she writes to Foe. The 'daughter' tells a story which Susan denies as it has no relation to the truth of her life (76). She denies the probability of the story's truth on the grounds that there is no pre-text for it: "The world is full of stories of mothers searching for sons and daughters they gave away once, long ago. But there are not stories of daughters searching for mothers" (77). She tells the girl, "you are father-born. You have no mother" (91), the father being the author, the mother the pre-text.

In the third section Susan has traced Foe to his hideout, once again in an attic which is not quite as she imagined it would be. Although Foe gives Susan and Friday food and shelter, although he takes Susan to his bed, he is her enemy, as his name implies, because he suppresses her creative impulse, attempting to confine it within his own narrow politics and puritanism. The incident of the daughter reveals that Foe is a devotee of the traditional style in which coincidence plays an important role (Hough, 1987:12). He is less interested in the island story than in the possibilities offered by the story of the lost daughter who turns up. This daughter provides a promising basis for a traditionally romantic story. According to Foe's theory, a novel consists of three parts: loss, quest, and recovery, or, beginning, middle and end. The story he wants to tell is the loss of the daughter, the quest in Brazil, the abandonment of the quest, the adventure of the island, the quest by the daughter, and the reunion of mother and daughter. The island episode is to be reduced to a mere novelty (117). Foe attempts to explain: "The island is not a story in itself, ... We can bring it to life only by setting it within a larger story" (117), which emphasises the importance of context.

Susan insists on the right to be father to her own story. She asks Foe, "Do you know the story of the Muse? ... The Muse is a woman, a goddess, who visits poets in the night and begets stories upon them" (126). When she literally mounts Foe in the manner of the Muse when she visits her poets, she asserts her right to dictate the nature of her story, "to father her offspring" (140). Her lament at there not being a man-muse is reflected in her acknowledgement of failure: "I wrote my memoir by candlelight in a windowless room, with the paper on my knee. Is that the reason, do you think, why my story was so dull - that my vision was blocked, that I could not see?" (127).

Susan revolts against becoming a mere receptacle of whatever story is stuffed in her, so that she becomes merely a hollow house of words, with no substance. She says, "I am not a story, Mr Foe. I may impress you as a story because I began my account of myself without preamble, slipping overboard into the water and striking out for shore. But my life did not begin in the waves ... not even to you do I owe proof that I am a substantial being with a substantial history in the world" (131). 
In spite of this assertion, Susan is full of doubt: "Who is speaking me? Am I a phantom too? To what order do I belong? And you: who are you?" Foe's reply to this is to assure her that no man has reason to believe that there is any more design in life than in the whimsical adventures of the imagination (135).

Friday's enigmatic silence is the pivotal point of the novel. Susan imagines this silence to be like a buttonhole neatly cross-stitched round, but waiting for the button (121). "The story of Friday's tongue is a story unable to be told, or unable to be told by me. That is to say, many stories can be told of Friday's tongue, but the true story is buried within Friday, who is mute. The true story will not be heard till by art we have found a means of giving voice to Friday" (118).

Referring to the incident when Friday paddles his log to where the ship supposedly sank, and scatters petals on the water, Foe uses the image of a great eye, across the dark pupil of which Friday paddles his log with impunity. The pupil represents the silent centre of the story, and it is left to the writer, to Foe and to Susan, to descend into that eye. If they don't do this, they "sail across the surface and come ashore none the wiser, and resume [their] old lives, and sleep without dreaming, like babes" (141). This suggests the supreme task of the author: that he should not only look at events and relate them truthfully, but that he should descend into them and interpret their meaning, so that he and the reader will emerge the wiser for the experience.

The fourth section is different from the rest of the novel, dreamlike and visionary. It offers three possible endings. The question raised by Mackie, "did Susan drown with her captain at sea? Or in the arms of Defoe? Is she the Muse, visiting the author, and is her story all a dream?" (1986:6), cannot be answered with any certainty, and neither is it necessary to do so. As it stands, the story has presented a wealth of thought-provoking material in which the 'reality' of the end is the least important factor. It is the speechless Friday who is the centre of the work, and his is the last word, as from his mouth issues the unbroken stream that fleetingly brushes Susan's face.

In this novel Coetzee has revealed the spurious nature of many of the myths ostensibly governing Western behaviour. The myth of Robinson Crusoe, the first formulator of the romantic colonial myth, is proved to be false, having falsified its source to begin with. This original colonizer does not manage to "make the desert bloom" (Coetzee, 1983:217), but keeps himself occupied with futile effort, preparing barren terraces. Despite the presence of a woman he feels no desire and fails to multiply and fill his colony. He dies when removed from this 'colonial paradise'. The true nature and spirit of colonialism has been proved to be domination, not development, its driving force a question of economics, not a burning desire to spread civilization.

In Coetzee's novel Friday does not kneel and place Cruso's foot on his head to symbolize his submission, but has his tongue cut out and is reduced to silence. The cynicism of modern attitudes is revealed: "We deplore the barbarism of whoever maimed him, yet have we, his later masters, not reason 
to be secretly grateful? For as long as he is dumb we can tell ourselves his desires are dark to us, and continue to use him as we wish" (148).

Finally, the importance of the writer in society is stressed. Skinner says that "The importance of J.M. Coetzee's fiction resides in his insights into the historical and philosophical context of our being, and its extension of our sensibilities" (1985a:113). It is the task of the writer to penetrate the dark pupil of the eye, and reveal society to itself. This dark pupil is also the bottom of the sea, among the wrecks, from where the mute voice must be given back its resonance and allowed to ascend.

\section{Bibliography}

Blake, Patricia. 1984. Armageddon. Time: 56, Jan. 27.

Coetzee, J.M. 1983. Life and Times of Michael K. Harmondsworth: Penguin.

Coetzee, J.M. 1986. Foe. Johannesburg: Ravan.

Cornwell, G. 1983. English literature. (In Galloway, F. ed. S. A. Literature 1981. Annual Literary Survey Series 2. Censal and Nelm. Johannesburg: Ad. Donker. p. 23-25)

Federman, I.R. 1973. Surfiction - a position. Partisan Review, 40(3):427-432.

Hegel, G.W.F. 1949. The Phenomenology of the Mind. Translated by J.B. Baillie. New York: Macmillan.

Hough, B. 1987. Foe is meer as 'n roman. Die Volksblad, 83: 12, Maart 7.

Mackie, Heather. 1986. Consummate literary brilliance of Coetzee emerges again. The Cape Times:6, Dec. 31.

Müller, Helene. 1985. Who is Michael K? Standpunte 175 38(1): 41-43, Feb.

Skinner, D.R. 1985a. Foe: J.M. Coetzee. Leadership 5(5):113.

Skinner, D.R. 1986b. Postmodern Palimpsest. Contrast 16(2): 82-85, Dec.

Smith, A.H. 1983. Three pairs of eyes. Frontline books: 28-29 Dec.

Wilhelm, Cherry. 1979. Olive Schreiner: Child of Queen Victoria; Stories, Dreams and allegories. Auetsa papers. Durban: University of Durban-Westville. p. 64-70. July. 